\title{
Examination of Optimum Test Conditions For a 3-Point Bending and Cutting Test To Evaluate Sound Emission of Wafer During Deformation
}

\author{
Erdem Carsanba $^{\mathrm{a}^{*}}$ And Gerhard Schleining ${ }^{\mathrm{b}}$ \\ ${ }^{a}$ Food Technology, Altınozu Vocational School of Agricultural Science, Mustafa Kemal University, Turkey \\ b Department of Food Science and Technology, BOKU-University of Natural Resources and Life Sciences, \\ Austria \\ ${ }^{*}$ Corresponding author \\ carsanba.erdem@gmail.com \\ TEL: +905412010950 \\ FAX: +903263112276
}

Received: 9 September 2016; Published online: 18 April 2018

Invited paper from the IFA-event "Food Rheology and Texture" e-conference for undergraduate $\&$ MASTER students

\begin{abstract}
The purpose of this study was to investigate optimum test conditions of acoustical-mechanical measurement of wafer analysed by Acoustic Envelope Detector attached to the Texture Analyser. Forcedisplacement and acoustic signals were simultaneously recorded applying two different methods (3-point bending and cutting test).

In order to study acoustical-mechanical behaviour of wafers, the parameters "maximum sound pressure", "total count peaks" and "mean sound value" were used and optimal test conditions of microphone position and test speed were examined. With a microphone position of $45^{\circ}$ angle and $1 \mathrm{~cm}$ distance and at a low test speed of $0.5 \mathrm{~mm} / \mathrm{s}$ wafers of different quality could be distinguished best. The angle of microphone did not have significant effect on acoustic results and the number of peaks of the force and acoustic signal decreased with increasing distance and test speed.
\end{abstract}

Keywords: Acoustic; Crispness; Texture; Wafer

\section{Introduction}

Quality of wafer products is generally examined and categorised according to textural property which is mainly called crispness considered as a primary textural attribute measured during bending and snapping of crispy foods at the first bite (Vickers, 1983; Duizer, 2004; Mallikarjunan, 2004; Martinez-Navarrete, Moraga, Talens, \& Chiralt, 2004). In general knowledge, as higher is the crispness value, higher is quality of wafer however determination of crispness and its perception by consumers greatly varies from individual to individual and from country to country (Bourne, 2002). This brings food researchers huge difficulty to identify parameter that is scientifically meaningful and easy to measure. In order to identify crispness, many sensory test panels have been still performed and large variations of results have been estimated. Although, sensory test methods are fundamental methods to determine crispness (Christensen \& Vickers, 1981; Vickers, 1984), due to the difficulties such as time consuming, not convenient for routine tests, requiring more statistical works and most of all providing participants who have 
good knowledge in texture attributes, other test techniques; mechanical-acoustical tests and their parameters are applied and evaluated by using some crispy foods which are mechanically brittle and emit sound during consumption (Duizer, 2004; Gregersen et al., 2015; Roudaut, Dacremont, Pamies, Colas, \& Le Meste, 2002; Zdunek, Cybulska, Konopacka, \& Rutkowski, 2011).

Sounds of crispy products during mechanical tests can be detected and evaluated by applying acoustical methods (Edmister \& Vickers, 1985; Seymour \& Hamann, 1988; Tesch, Normand, \& Peleg, 1996; Duizer, 2004). Acoustic detection devices connected to texture analyser can provide to obtain information about crispness from the acoustic and force/displacement curves acquired during mechanical measurements of wafer and parameters on these curves can be calculated and correlated by sensory test results.

Recently, related studies were carried out by some researches and good correlation values between sensory and acoustical-mechanical tests were estimated in different types of crispy foods (Dematte et al., 2014; Piazza \& Giovenzana, 2015; Wiktor et al., 2016; Zdunek et al., 2011; Saeleaw, Duerrschmid, \& Schleining, 2012; Chanvrier, Jakubczyk, Gondek, \& Gumy, 2014; Blonska, Marzec, \& Blaszczyk, 2014; Giacosa et al., 2016; Jakubczyk, Gondek, \& Tryzno, 2017). Moreover, parameters and deformation techniques were improved and test conditions such as test speed and microphone location were noticed as critical factors affecting the results of acoustical methods in some studies at the beginning of this type of researches (Chen, Karlsson, \& Povey, 2005; Varela, Chen, Fiszman, \& Povey, 2006; Varela, Salvador, \& Fiszman, 2008).

In this study, in order to distinguish quality differences of wafer samples in terms of crispness, acoustical-mechanical tests were carried out by using acoustic envelop detector and microphone attached to texture analyser. Two different fracturing methods (3-point bending and cutting test methods) and acoustical parameters were used and optimum test conditions of microphone positions and test speeds were examined.

\section{Materials and Methods}

\subsection{Materials}

Nine different brands of wafers; Bella, Manner, Sweet Gold, Napoli, Biscoteria, Jadro, Fin Carre (Normal), Fin Carre Strawberry and Fin Carre Limon with the dimension of $16 \mathrm{~mm}$ thickness, $51 \mathrm{~mm}$ length and $18 \mathrm{~mm}$ width were purchased from local markets. Samples were kept in its original package in a dark place at about $24^{\circ} \mathrm{C}$. For each experiment, in order to avoid humidity absorption, a new package was opened and in case samples were not of the same size, a sharp knife was used for trimming. All samples were measured within maximum 20 minutes.

\subsection{Texture measurement}

All measurements were carried out with a texture analyzer TAXT.plus (Stable Micro Systems, Surrey, U.K) connected with the standard microphone (Brüel Kjaer, Type 2671 Naerum, Denmark). The reaction force was determined by a $5 \mathrm{~kg}$ load cell and the microphone was calibrated with the acoustic calibrator type 4231 (Brüel Kjaer) at 94 and $114 \mathrm{~dB}$ sound pressure level (SPL). The amplifier was set to level 4 .

Chen et al. (2005) explained that the intensity of the vibration of original source, the travel distance and the available sound paths affect the strength of the sound. Therefore, the position of the detecting microphone is important to measure acoustic signals. On this huge random of possibilities, nine positions were selected for microphone. Tests were made in 3 different angles $\left(0^{\circ}, 45^{\circ}, 90^{\circ}\right)$ and 3 different distances $(1 \mathrm{~cm}, 5$ $\mathrm{cm}$ and $10 \mathrm{~cm}$ ) for each angle totally nine different location. Product Bella were used to investigate best microphone position by applying 3-point bending at $1.0 \mathrm{~mm} / \mathrm{s}$ test speed.

Two deformation methods were used to investigate crispness of wafer samples; 3-point bending (Alvarez, Saunders, Vincent, \& Jeronimidis, 2000; Baltsavias, 1996; Castro-Prada, Luyten, Lichtendonk, Hamer, \& Van Vliet, 2007; Chen et al., 2005) and cutting test methods (CastroPrada et al., 2007). For the 3-point bending, the sample lays on two supports and a compressing 
bar moves down between these supports, bending the food until it snaps (Table 1). For the cutting test the samples lays on a flat metal platform, and a trapezium-shaped stainless steel blade $(60$ $\mathrm{mm}$ length, $19 \mathrm{~mm}$ height and $0.65 \mathrm{~mm}$ width) cuts the sample to for a distance of $9 \mathrm{~mm}$ (Table 2).

Four different test speeds of $0.1,0.5,1.0$ and 1.5 $\mathrm{mm} / \mathrm{s}$ were applied to examine the optimum test speed for the 3-point bending and cutting test (see table 1 and 2 for test settings). Measurements were repeated ten times for the product Bella.

Parameters of maximum sound pressure (MSP), total count peaks (TCP) and mean sound value (MV) were calculated from the acousticdisplacement curve within a range from 0 to 10 resp. $20 \mathrm{~mm}$ using the Exponent software (Stable Micro System Surrey, U.K) (see Figure 1 and 2).

\section{$2.3 \quad$ Statistical analysis}

Results were studied and evaluated by SPSS software with Analysis of Variance (ANOVA) and multiple range tests.

\section{$3 \quad$ Results and Discussions}

\subsection{Selection of the microphone position}

In order to find the best position for the microphone, nine different positions; $0^{\circ}-1 \mathrm{~cm}, 45^{\circ}-1$ $\mathrm{cm}, 90^{\circ}-1 \mathrm{~cm}, 0^{\circ}-5 \mathrm{~cm}, 45^{\circ}-5 \mathrm{~cm}, 90^{\circ}-5 \mathrm{~cm}, 0^{\circ}-10$ $\mathrm{cm}, 45^{\circ}-10 \mathrm{~cm}, 90^{\circ}-10 \mathrm{~cm}$ and test speed of 1.0 $\mathrm{mm} / \mathrm{s}$ was applied for the product "Bella" with the 3-point bending method, which has been used for acoustic tests by several researchers (CastroPrada et al., 2007; Chen et al., 2005).

The maximum sound pressure (MSP) and the total count peaks (TCP) were examined to see in which position these parameters have the smallest variability (see Figure 3 and 4). Table 3 and Table 4 show standard deviations (SD) and average values of MSP and TCP at the nine different microphone positions.

Table 3 demonstrates that generally the average values of the MSP and TCP decrease and the standard deviation of MSP increase with the microphone distance. For TCP there was no significant effect on the standard deviation.

Figure 3 and Figure 4 show that the angle had no significant effect on the MSP and TCP. This was also observed by Chen et al. (2005). Considering Table 3, optimum microphone angle and distance can be selected as $45^{\circ}$ angle- $1 \mathrm{~cm}$ distance since at this position lower standard deviations and high average values of MSP were measured compared to the other positions.

Because of low variability and high values at small distance for both parameters, the choice of the best microphone position according to the MSP and TCP was $1 \mathrm{~cm}$ distance $45^{\circ}$.

\subsection{Selection of the test speed}

The microphone position of $45^{\circ}$ angle and $1 \mathrm{~cm}$ distance was used to select best test speed. Parameters of MSP, TCP and mean sound value (MV) were evaluated from the obtained curves (Figure 1 and 2) and results are illustrated in Table 4 shows that how variances of MSP, TCP and MV change as a function of test speed in 10 replications (Bella brand of sample tested for each speed within ten replications).

Table 4 shows that for both test methods in general the average values for values MSP and MV increase with the test speed, whereas the values of TCP decrease for both tests. This could be explained that with higher speeds some acoustic events were lost. Statistically, the increase of MSP was not significant.

The values of MSP and MV of the 3-Point bending method were higher than for the cutting test, whereas the TCP values were lower except at 0.1 $\mathrm{mm} / \mathrm{s}$ test speed. The higher number of peaks for the cutting test is obviously due to the longer measuring time.

For the 3-point bending test the standard deviations decrease with increasing test speed for TCP but are more or less the same for MSP and opposite for MV. For the cutting test the standard deviations generally decrease with increasing test speed for TCP and MV.

Chen et al. (2005) explained that the reliability of acoustic emission detector is higher in distin- 
Table 1: Settings of 3-point bending test method

\begin{tabular}{ll} 
Load cell & $5 \mathrm{~kg}$ \\
Test Type & Return to start \\
Pre-test speed & $0.8 \mathrm{~mm} / \mathrm{s}, 0.4 \mathrm{~mm} / \mathrm{s}, 0.8 \mathrm{~mm} / \mathrm{s}$ and $1.4 \mathrm{~mm} / \mathrm{s}$ \\
Test speeds & $0.1 \mathrm{~mm} / \mathrm{s}, 0.5 \mathrm{~mm} / \mathrm{s}, 1.0 \mathrm{~mm} / \mathrm{s}$ and $1.5 \mathrm{~mm} / \mathrm{s}$ \\
Back-test speed & $10 \mathrm{~mm} / \mathrm{s}$ \\
Distance & $16 \mathrm{~mm}$ \\
Test mode & Compression \\
Microphone position & 0 degree (parallel to sample) and $1 \mathrm{~cm}$ distance to sample \\
Data acquisition rate & $500 \mathrm{pps}$ \\
Envelope Corner Frequency & $3.125 \mathrm{KHz}$ \\
\hline
\end{tabular}

Table 2: Settings of cutting test method

\begin{tabular}{ll}
\hline Load cell & $5 \mathrm{~kg}$ \\
Test Type & Return to start \\
Pre-test speed & $0.8 \mathrm{~mm} / \mathrm{s}, 0.4 \mathrm{~mm} / \mathrm{s}, 0.8 \mathrm{~mm} / \mathrm{s}$ and $1.4 \mathrm{~mm} / \mathrm{s}$ \\
Test speeds & $0.1 \mathrm{~mm} / \mathrm{s}, 0.5 \mathrm{~mm} / \mathrm{s}, 1.0 \mathrm{~mm} / \mathrm{s}$ and $1.5 \mathrm{~mm} / \mathrm{s}$ \\
Back-test speed & $10 \mathrm{~mm} / \mathrm{s}$ \\
Distance & $16 \mathrm{~mm}$ \\
Test mode & Compression \\
Microphone position & 0 degree (parallel to sample) and $1 \mathrm{~cm}$ distance to sample \\
Data acquisition rate & $500 \mathrm{pps}$ \\
Envelope Corner Frequency & $3.125 \mathrm{KHz}$ \\
\hline
\end{tabular}

Table 3: Maximum sound pressure (MSP) and total count peak (TCP) for the 3-point bending test at 1.0 $\mathrm{mm} / \mathrm{s}$ test speed at different microphone positions, carried out with wafer Bella. Values are expressed as average \pm standard deviation $(n=10)$. Different indices indicate significantly different values per column based on the Tukey test, $\mathrm{p}<0.05$

\begin{tabular}{|c|c|c|c|}
\hline \multirow{2}{*}{\multicolumn{2}{|c|}{ Positions }} & \multicolumn{2}{|c|}{ Acoustic Parameters } \\
\hline & & MSP & TCP \\
\hline $0^{\circ}-1 \mathrm{~cm}$ & & $79.81 \pm 2.86^{c d}$ & $232.80 \pm 45.07^{a b c}$ \\
\hline $0^{\circ}-5 \mathrm{~cm}$ & & $75.82 \pm 3.57^{b c}$ & $265.70 \pm 37.73^{c}$ \\
\hline $0^{\circ}-10 \mathrm{~cm}$ & & $70.82 \pm 3.50^{a}$ & $204.90 \pm 34.41^{a b}$ \\
\hline $45^{\circ}-1 \mathrm{~cm}$ & & $80.39 \pm 2.32^{d}$ & $227.40 \pm 51.97^{a b c}$ \\
\hline $45^{\circ}-5 \mathrm{~cm}$ & & $75.73 \pm 2.59^{b c}$ & $223.90 \pm 51.27^{a b c}$ \\
\hline $45^{\circ}-10 \mathrm{~cm}$ & & $70.86 \pm 4.58^{a}$ & $193.80 \pm 25.89^{a}$ \\
\hline $90^{\circ}-1 \mathrm{~cm}$ & & $81.95 \pm 3.21^{d}$ & $253.30 \pm 21.70^{b c}$ \\
\hline $90^{\circ}-5 \mathrm{~cm}$ & & $75.83 \pm 2.95^{b c}$ & $249.30 \pm 32.56^{b c}$ \\
\hline $90^{\circ}-10 \mathrm{~cm}$ & & $72.12 \pm 2.61^{a b}$ & $193.90 \pm 27.07^{a}$ \\
\hline \multirow{2}{*}{ ANOVA } & F-value & 16.813 & 4.722 \\
\hline & $\mathrm{P}$ value & 0.000 & 0.000 \\
\hline
\end{tabular}

IJFS | April $2018 \mid$ Volume $7 \mid$ pages 13-23 


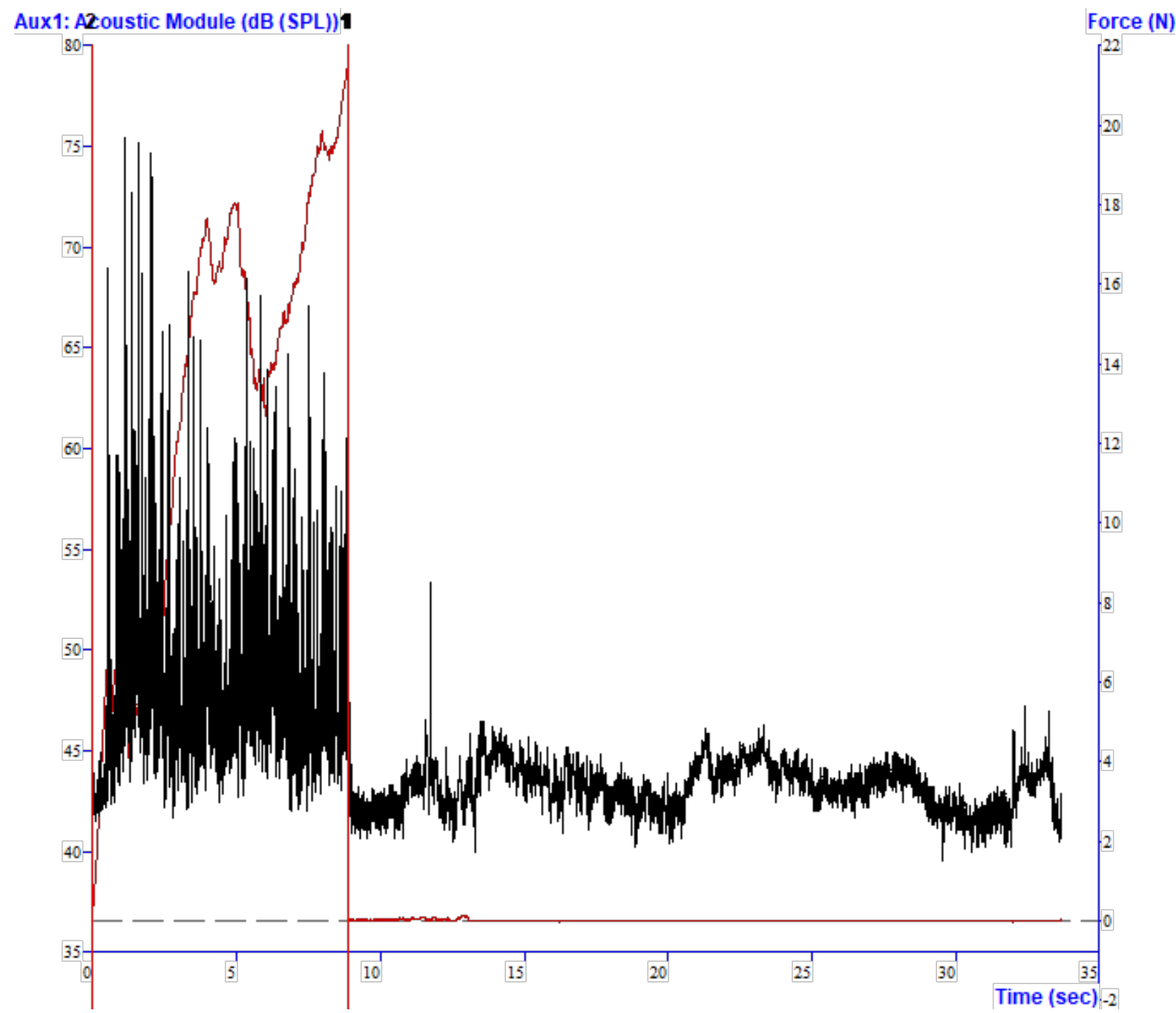

Figure 1: Results (acoustic and force) of the 3-point bending method (Red line corresponds forcedisplacement curve and black line corresponds acoustic-displacement curve) 


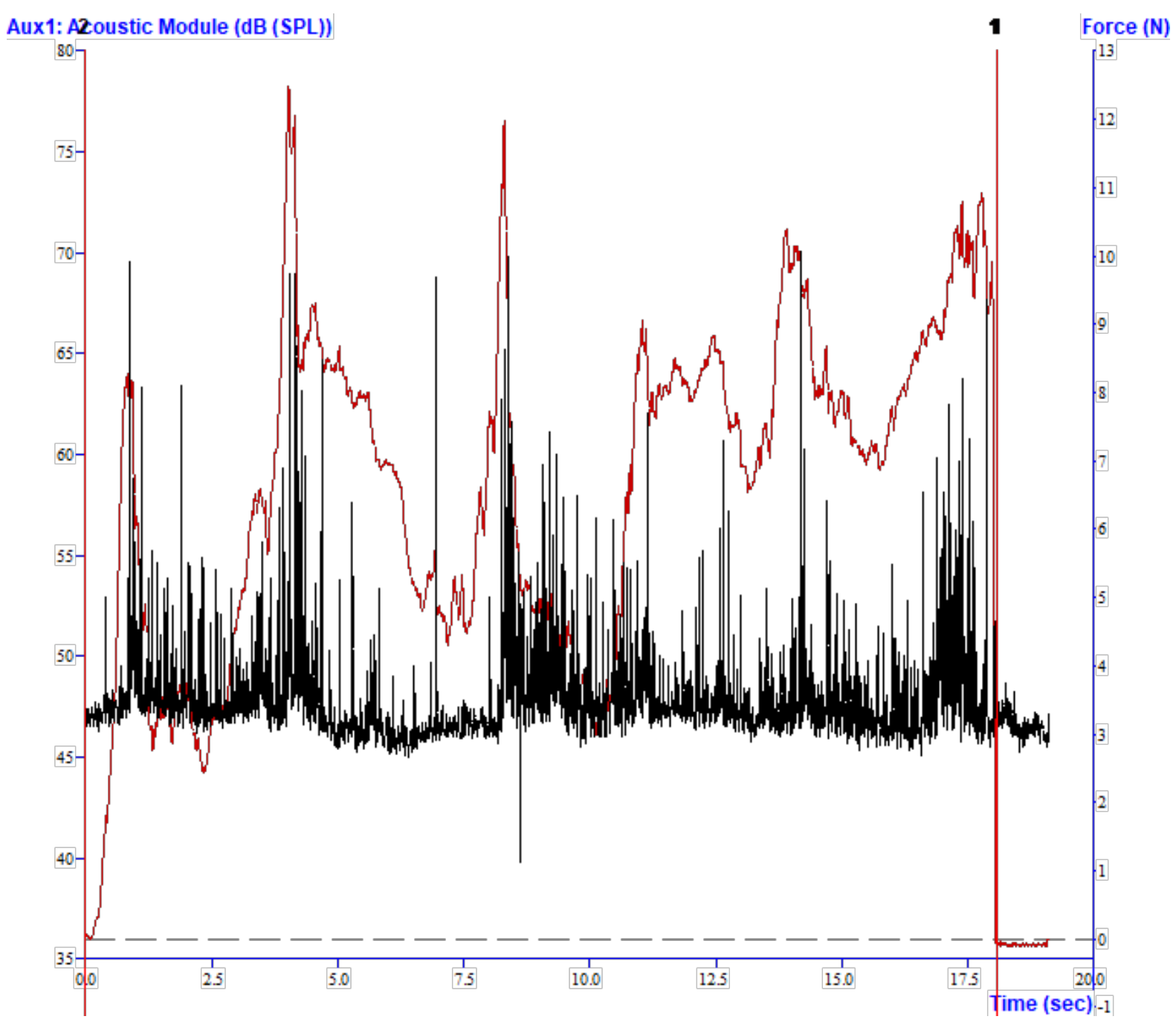

Figure 2: Results (acoustic and force) of the Cutting test method (Red line corresponds forcedisplacement curve and black line corresponds acoustic-displacement curve) 


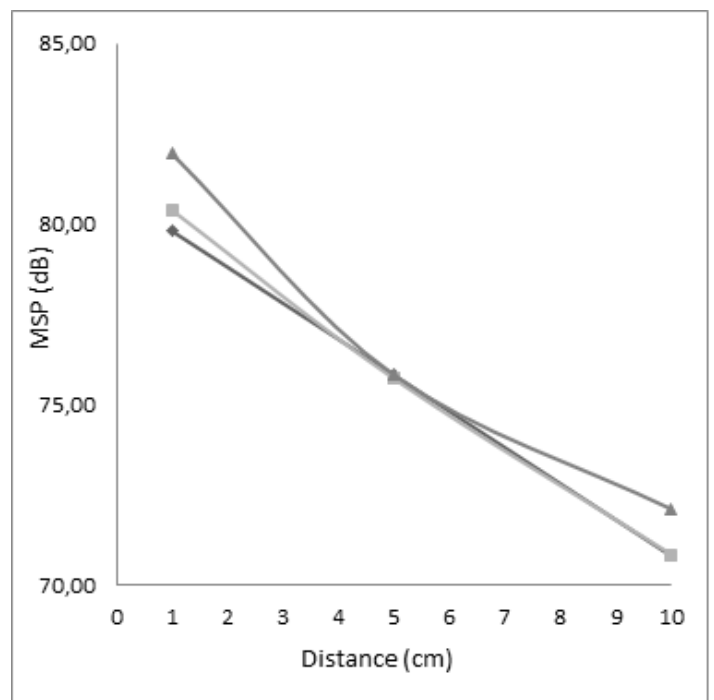

Figure 3: Maximum sound pressure (MSP) at various distances and angles in 3 -point bending $\operatorname{method}\left(\boldsymbol{\square}-45^{\circ}, \diamond-0^{\circ}, \mathbf{\Delta}-90^{\circ}\right)$

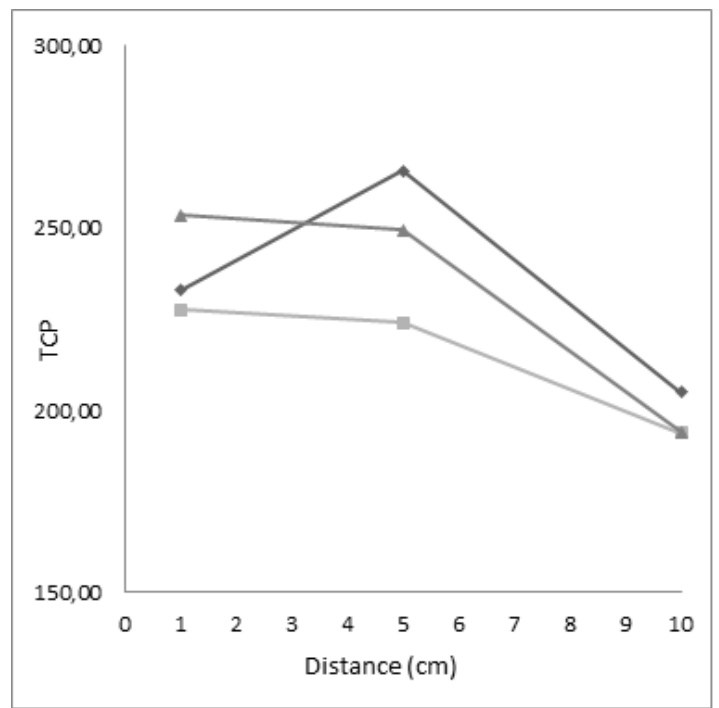

Figure 4: Total count peak (TCP) at various distances and angles in 3-point bending method ( $\left.45^{\circ}, \diamond-0^{\circ}, \mathbf{\Delta}-90^{\circ}\right)$ guishing acoustic signals during breakup of biscuits at low speeds than fast speeds. It was noticed that the device probably fails to pick up all individual acoustic events at high testing test speed for some products. This is due to a too large integration time of the acoustic emission detector that makes the device unable to distinguish two sequential acoustic events. The current default integration time works well for the majority of crispy foods at a reasonably low test speed, but a shorter integration time should be considered for acoustic-rich products. Especially variations of other acoustic parameters, such as TCP, showed an obviously loss of this information at high speeds.

Although the variability was lower at high test speeds and especially high at $0.1 \mathrm{~mm} / \mathrm{s} 0.5 \mathrm{~mm} / \mathrm{s}$ was selected in order not to lose acoustical events at high test speeds.

\subsection{Comparison of quality differences of wafers by means of crispness}

A test speed of $0.5 \mathrm{~mm} / \mathrm{s}$ and microphone position of $45^{\circ}$ angle with- $1 \mathrm{~cm}$ distance from the sample were used to distinguish quality differences of nine brands of wafers by applying a 3point bending test.

Table 5 illustrates the average values and standard deviations of MSP, TCP and MV of the brands of wafers. There are significant differences $(\mathrm{p}<0.05)$ between MSP, TCP and MV values of nine brands of wafers.

The products Jadro, Fin Carre, Fin Carre Lemon, Fin Carre Strawberry and Napoli were placed in same group regarding MSP values more than $80 \mathrm{~dB}$ (see Fig. 5 and Table 5). However, highest TCP values more than 440 were examined for the products Napoli, Sweet Gold, Fin Carre Lemon and Fin Carre Strawberry. In addition, highest MV values more than $49.50 \mathrm{~dB}$ were also obtained for products Fin Carre, Fin Carre Strawberry and Sweet Gold.

According to these results, generally products Fin Carre group (Fin Carre, Fin Carre Lemon and Fin Carre Strawberry) and Sweet Gold displayed highest values of acoustic parameters. Crispness is evaluated with sound events dur- 


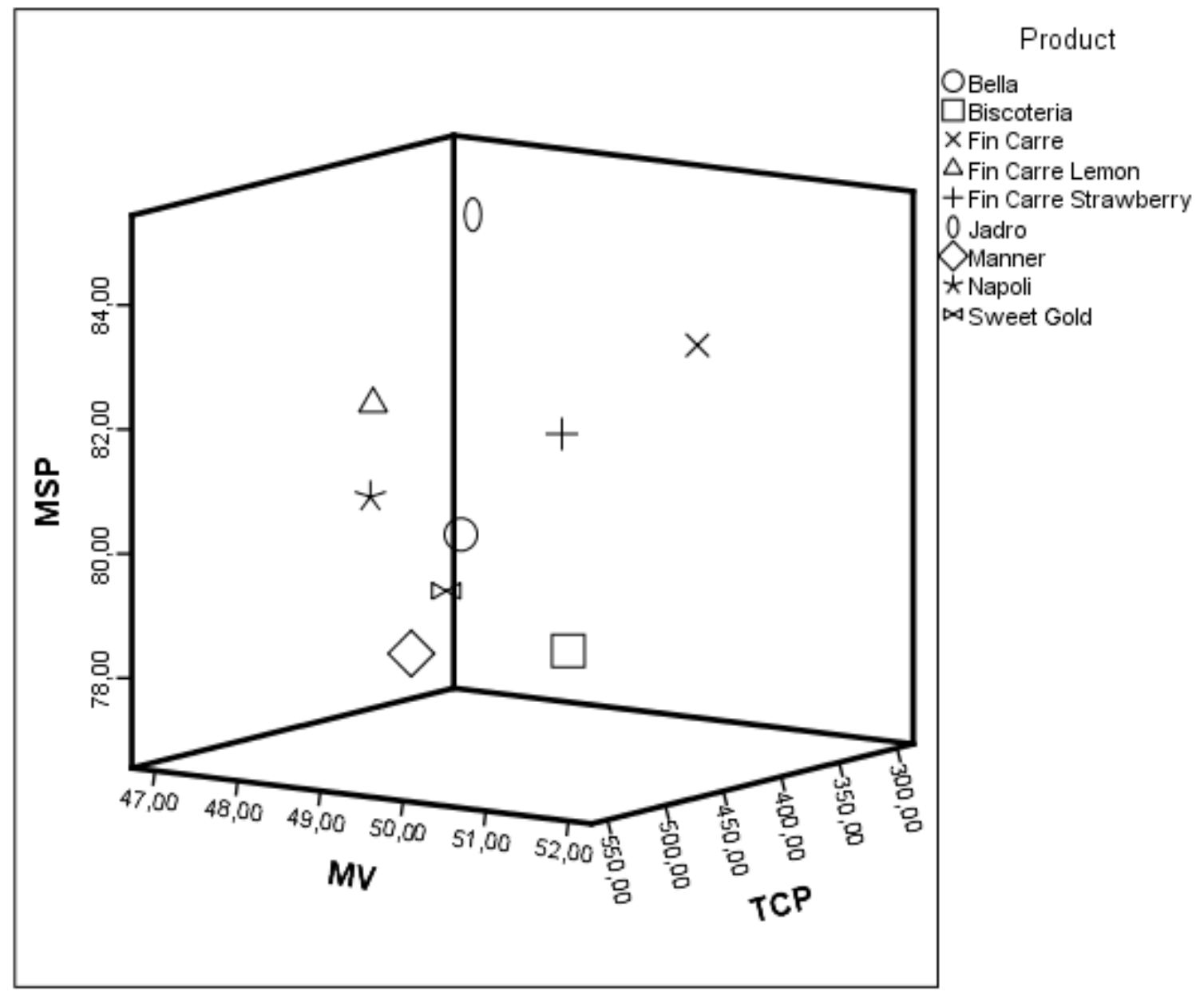

Figure 5: Distribution of brands of wafers as functions of Maximum sound pressure, Total count peak and Mean sound value

ing mechanical deformations and as higher number of sound events, the higher is the crispness. Based on this, it could be said that products Fin Carre group and Sweet Gold are more crispy than the other 5 brands of wafers.

\section{Conclusion}

Comparing the 2 methods, it could be concluded that the 3 -point bending test is more convenient and reliable than the cutting test since there were difficulties to distinguish acoustical events whether caused by friction of the knife or by breaking of the wafer.
The best microphone position was selected as $45^{\circ}$ and $1 \mathrm{~cm}$ distance from the breaking point of the wafer due to lower variability. The smaller the distance the higher are the values of the evaluated parameters and in general the lower the variability. The angle of microphone did not significant effect. The results of the test speed measurements displayed that especially number of recorded peaks at high test speeds (1.0 and $1.5 \mathrm{~mm} / \mathrm{s}$ ) were less than at slower test speeds, because there is loss of acoustic events at high speeds. As the evaluated parameters showed a much higher variability at the lowed test speed of $0.1 \mathrm{~mm} / \mathrm{s}, 0.5 \mathrm{~mm} / \mathrm{s}$ was chosen. 
Table 4: Maximum sound pressure (MSP), total count peak (TCP) and mean sound value (MV) for the 3-point bending and cutting test at different test speeds, carried out with Product Bella. Values are expressed as average \pm standard deviation $(n=10)$. Different indices indicate significantly different values per column based on the Tukey test, $\mathrm{p}<0.05$.

\begin{tabular}{rrrrr}
\hline & \multicolumn{4}{c}{ 3-Point Bending test } \\
\cline { 2 - 5 } Test Speeds & MSP & TCP & MV \\
$0.1 \mathrm{~mm} / \mathrm{s}$ & $78.31 \pm 3.31^{a}$ & $1123.0 \pm 120.96^{c}$ & $42.97 \pm 0.60^{a}$ \\
$0.5 \mathrm{~mm} / \mathrm{s}$ & $79.65 \pm 2.47^{a}$ & $374.7 \pm 70.94^{b}$ & $48.04 \pm 0.79^{b}$ \\
$1.0 \mathrm{~mm} / \mathrm{s}$ & $79.81 \pm 2.86^{a}$ & $232.8 \pm 45.07^{a}$ & $51.65 \pm 1.17^{c}$ \\
$1.5 \mathrm{~mm} / \mathrm{s}$ & $80.48 \pm 2.61^{a}$ & $163.8 \pm 25.60^{a}$ & $52.02 \pm 0.84^{c}$ \\
ANOVA & F-value & 1.030 & 349.263 & 230.482 \\
& P-value & 0.390 & 0.000 & 0.000 \\
& & & Cutting Test & \\
\cline { 2 - 5 } & & $\mathrm{MSP}$ & $\mathrm{TCP}$ & $\mathrm{MV}$ \\
$0.1 \mathrm{~mm} / \mathrm{s}$ & $75.06 \pm 4.05^{b}$ & $989.2 \pm 127.57^{d}$ & $46.12 \pm 0,36^{a}$ \\
$0.5 \mathrm{~mm} / \mathrm{s}$ & $70.89 \pm 2.60^{a}$ & $448.7 \pm 67.06^{c}$ & $47.93 \pm 0.34^{b}$ \\
$1.0 \mathrm{~mm} / \mathrm{s}$ & $74.49 \pm 3.35^{a b}$ & $349.0 \pm 23.43^{b}$ & $49.67 \pm 0.30^{c}$ \\
$1.5 \mathrm{~mm} / \mathrm{s}$ & $73.96 \pm 3.28^{a b}$ & $256.4 \pm 19.16^{a}$ & $50.61 \pm 0.32^{d}$ \\
ANOVA & 3.071 & 198.972 & 354.031 \\
& F-value & 0.040 & 0.000 & 0.000 \\
\hline P-value & 0 & & \\
\hline
\end{tabular}

Table 5: Maximum sound pressure (MSP), total count peak (TCP) and mean sound value (MV) for the 3 -point bending at optimum test conditions (at $0.5 \mathrm{~mm} / \mathrm{s}$ test speed and $45^{\circ}-1 \mathrm{~cm}$ microphone position), carried out with 9 different brand of wafers. Values are expressed as average \pm standard deviation $(\mathrm{n}=10)$. Different indices indicate significantly different values per column based on the Tukey test, $\mathrm{p}<$ 0.05 .

\begin{tabular}{|c|c|c|c|c|}
\hline \multicolumn{2}{|c|}{ Brand of Wafers } & MSP & TCP & MV \\
\hline \multicolumn{2}{|l|}{ Manner } & $77.89 \pm 3.38^{a}$ & $411.10 \pm 37.29^{b c}$ & $47.96 \pm 0,32^{b}$ \\
\hline \multicolumn{2}{|l|}{ Fin Carre } & $83.23 \pm 2.70^{c}$ & $385.40 \pm 39.63^{a b}$ & $51.06 \pm 0,59^{g}$ \\
\hline \multicolumn{2}{|l|}{ Napoli } & $81.05 \pm 1.06^{a b c}$ & $515.70 \pm 84.87^{d}$ & $48.93 \pm 0,70^{c d}$ \\
\hline \multicolumn{2}{|c|}{ Fin Carre Lemon } & $82.20 \pm 2.18^{b c}$ & $464.80 \pm 102.36^{b c d}$ & $48.25 \pm 0,63^{b c}$ \\
\hline \multicolumn{2}{|c|}{ Sweet Gold } & $79.62 \pm 2.41^{a b}$ & $505.90 \pm 44.66^{c d}$ & $49.71 \pm 0,82^{e f}$ \\
\hline \multicolumn{2}{|c|}{ Fin Carre Strawberry } & $81.92 \pm 3.37^{b c}$ & $441.00 \pm 50.31^{b c d}$ & $50.20 \pm 0,49^{f}$ \\
\hline \multicolumn{2}{|l|}{ Jadro } & $84.32 \pm 1.64^{c}$ & $302.20 \pm 80.37^{a}$ & $47.18 \pm 0,56^{a}$ \\
\hline \multicolumn{2}{|l|}{ Biscoteria } & $77.93 \pm 3.31^{a}$ & $366.20 \pm 107.62^{a b}$ & $49.23 \pm 0,47^{d e}$ \\
\hline \multicolumn{2}{|l|}{ Bella } & $79.65 \pm 2.47^{a b}$ & $374.70 \pm 70.94^{a b}$ & $48.05 \pm 0,79^{b}$ \\
\hline \multirow{2}{*}{ ANOVA } & F-value & 7.488 & 9.111 & 40.135 \\
\hline & P-value & 0.000 & 0.000 & 0.000 \\
\hline
\end{tabular}


From the different brands of wafers, the products Fin Carre group and Sweet Gold were examined as more crispy due to their higher MSP, TCP and MV values.

In conclusion, this study can lead further investigations on wafer quality in terms of crispness which is generally difficult to determine, by using obtained test conditions and acoustic parameters from acoustical-mechanical measurements. Although, sensory test methods were carried out to determine crispness of wafers, using fast and reliable methods such as acoustical-mechanical tests in industry is important. With this method conditions and parameters, quality of wafer can be distinguished by means of simple and reproducible test.

\section{References}

Alvarez, M. D., Saunders, D. E. J., Vincent, J. F. V., \& Jeronimidis, G. (2000). An engineering method to evaluate the crisp texture of fruit and vegetables. Journal of Texture Studies, 31(4), 457-473. doi:10.1111/ j.1745-4603.2000.tb00302.x

Baltsavias, A. (1996). Mechanical properties of short doughs and their corresponding biscuits. Baltsavias.

Blonska, A., Marzec, A., \& Blaszczyk, A. (2014). Instrumental evaluation of acoustic and mechanical texture properties of shortdough biscuits with different content of fat and inulin. Journal of Texture Studies, 45(3), 226-234. doi:10.1111/jtxs.12068

Bourne, M. (2002). Food texture and viscosity: concept and measurement. Academic press.

Castro-Prada, E. M., Luyten, H., Lichtendonk, W., Hamer, R. J., \& Van Vliet, T. (2007). An improved instrumental characterization of mechanical and acoustic properties of crispy cellular solid food. Journal of Texture Studies, 38(6), 698-724.

Chanvrier, H., Jakubczyk, E., Gondek, E., \& Gumy, J.-C. (2014). Insights into the texture of extruded cereals: structure and acoustic properties. Innovative Food Science \&5 Emerging Technologies, 24(SI), 6168. doi:10.1016/j.ifset.2013.11.013
Chen, J. S., Karlsson, C., \& Povey, M. (2005). Acoustic envelope detector for crispness assessment of biscuits. Journal of Texture Studies, 36(2), 139-156. doi:10.1111/ j . 1745-4603.2005.00008.x

Christensen, C. M. \& Vickers, Z. M. (1981). Relationships of chewing sounds to judgments of food crispness. Journal of Food Science, 46(2), 574-578. doi:10.1111/j.1365-2621. 1981.tb04914.x

Dematte, M. L., Pojer, N., Endrizzi, I., Corollaro, M. L., Betta, E., Aprea, E., ... Gasperi, F. (2014). Effects of the sound of the bite on apple perceived crispness and hardness. Food Quality and Preference, 38, 58-64. doi:10.1016/j.foodqual.2014.05.009

Duizer, L. M. (2004). 6 - sound input techniques for measuring texture. In D. Kilcast (Ed.), Texture in food (pp. 146-166). Woodhead Publishing Series in Food Science, Technology and Nutrition. Woodhead Publishing. doi:https://doi.org/10.1533/ 978185538362.2.146

Edmister, J. A. \& Vickers, Z. M. (1985). Instrumental acoustical measures of crispness in foods. Journal of Texture Studies, 16(2), 153-167. doi:10.1111/j.1745-4603.1985. tb00688.x

Giacosa, S., Belviso, S., Bertolino, M., Dal Bello, B., Gerbi, V., Ghirardello, D., ... Rolle, L. (2016). Hazelnut kernels (corylus avellana 1.) mechanical and acoustic properties determination: comparison of test speed, compression or shear axis, roasting, and storage condition effect. Journal of Food Engineering, 173, 59-68. doi:10.1016/j . jfoodeng.2015.10.037

Gregersen, S. B., Povey, M. J. W., Kidmose, U., Andersen, M. D., Hammershøj, M., \& Wiking, L. (2015). Identification of important mechanical and acoustic parameters for the sensory quality of cocoa butter alternatives. Food Research International, 76, 637644.

Jakubczyk, E., Gondek, E., \& Tryzno, E. (2017). Application of novel acoustic measurement techniques for texture analysis of coextruded snacks. LWT-Food Science and Technology, 75, 582-589. doi:10.1016/j.lwt. 2016.10.013 
Mallikarjunan, P. (2004). 4 - understanding and measuring consumer perceptions of crispness. In D. Kilcast (Ed.), Texture in food (pp. 82-105). Woodhead Publishing Series in Food Science, Technology and Nutrition. Woodhead Publishing. doi:https : / / doi . org /10.1533/978185538362.1.82

Martinez-Navarrete, N., Moraga, G., Talens, P., \& Chiralt, A. (2004). Water sorption and the plasticization effect in wafers. International Journal of Food Science and Technology, 39(5), 555-562. doi:10.1111/j.13652621.2004.00815.x

Piazza, L. \& Giovenzana, V. (2015). Instrumental acoustic-mechanical measures of crispness in apples. Food Research International, 69, 209-215. doi:10.1016/j.foodres. 2014.12.041

Roudaut, G., Dacremont, C., Pamies, B. V., Colas, B., \& Le Meste, M. (2002). Crispness: a critical review on sensory and material science approaches. Trends in Food Science $\&$ Technology, 13(6-7), 217-227. doi:10.1016/ S0924-2244(02)00139-5

Saeleaw, M., Duerrschmid, K., \& Schleining, G. (2012). The effect of extrusion conditions on mechanical-sound and sensory evaluation of rye expanded snack. Journal of Food Engineering, 110(4), 532-540. doi:10.1016/ j.jfoodeng.2012.01.002

Seymour, S. K. \& Hamann, D. D. (1988). Crispness and crunchiness of selected low moisture foods. Journal of Texture Studies, 19(1), 79-95. doi:10.1111/j. 1745 - 4603 . 1988.tb00926.x

Tesch, R., Normand, M. D., \& Peleg, M. (1996). Comparison of the acoustic and mechanical signatures of two cellular crunchy cereal foods at various water activity levels. Journal of the Science of Food and Agriculture, 70(3), 347-354. doi:10.1002 / (SICI) 1097 0010(199603) 70:3〈347::AID-JSFA510〉3.0. $\mathrm{CO} ; 2-\mathrm{B}$

Varela, P., Chen, J., Fiszman, S., \& Povey, M. J. W. (2006). Crispness assessment of roasted almonds by an integrated approach to texture description: texture, acoustics, sensory and structure. Journal of Chemometrics, 20(6-7), 311-320. doi:10.1002/ cem.1029
Varela, P., Salvador, A., \& Fiszman, S. M. (2008). Methodological developments in crispness assessment: effects of cooking method on the crispness of crusted foods. LWT-Food Science and Technology, 41(7), 1252-1259. doi:10.1016/j.lwt.2007.08.008

Vickers, Z. M. (1983). Pleasantness of food sounds. Journal of Food Science, 48(3), 783-786. doi:10.1111/j.1365-2621.1983. tb14898.x

Vickers, Z. M. (1984). Crispness and crunchiness - a difference in pitch. Journal of Texture Studies, 15(2), 157-163. doi:10.1111/j . 1745-4603.1984.tb00375.x

Wiktor, A., Gondek, E., Jakubczyk, E., Nowacka, M., Dadan, M., Fijalkowska, A., \& Witrowa-Rajchert, D. (2016). Acoustic emission as a tool to assess the changes induced by pulsed electric field in apple tissue. Innovative Food Science \& Emerging Technologies, 37(C, SI), 375-383. doi:10.1016/j.ifset.2016.04.008

Zdunek, A., Cybulska, J., Konopacka, D., \& Rutkowski, K. (2011). Evaluation of apple texture with contact acoustic emission detector: a study on performance of calibration models. Journal of Food Engineering, 106(1), 80-87. doi:10.1016/j.jfoodeng. 2011.04 .011 